\title{
Diversity and determinants of traditional water conservation technologies in the Eastern Cape Province, South Africa
}

\author{
Buntu Fanteso $\cdot$ Kowiyou Yessoufou ${ }^{\mathbb{D}}$
}

Received: 31 January 2021 / Accepted: 29 January 2022 / Published online: 8 February 2022

(C) The Author(s), under exclusive licence to Springer Nature Switzerland AG 2022

\begin{abstract}
Water scarcity remains a major threat to most rural areas in Africa due to heavy reliance on rainfed agriculture. This prompts the need to document and understand the determinants of traditional knowledge of water conservation practices. Our aim here is to document and identify the determinants of people's knowledge of traditional knowledge of water conservation in the South Africa's Eastern Cape province. A mixed research method was used. Purposive approach was used to collect data, i.e., elderly people were targeted during the face-to-face pre-COVID-19 pandemic interviews on the basis that traditional knowledge increases with age. However, people of different age groups were also included in the study especially when we employed only online questionnaire during the pandemic. We used questionnaire to collect all the data, and 93 people responded in total to our questions. We documented 10 traditional water conservation technologies. We identified rainfall variation, water quality issues, and increased water demand as the major challenges linked to these technologies, while easy access and the amount of water
\end{abstract}

Supplementary information The online version contains supplementary material available at https://doi. org/10.1007/s10661-022-09848-2.

B. Fanteso $\cdot$ K. Yessoufou $(\bowtie)$

Department of Geography, Environmental Management and Energy Studies, University of Johannesburg, APK Campus, Johannesburg 2006, South Africa

e-mail: kowiyouy@uj.ac.za harvested are reported as benefits of these technologies. We found that traditional knowledge is not influenced by age $(\beta=-0.006 \pm 0.01, P=0.64)$ or gen$\operatorname{der}(\beta=-0.16 \pm 0.25, P=0.64)$ but rather correlates positively with geographic location, irrespective of the starting point of the distance measurement (distance from Port Elizabeth city: $\beta=0.002 \pm 0.0008$, $P=0.004$; distance from Ngqushwa village: $\beta=0.0024 \pm 0.0009, \quad P=0.008)$. Counterintuitively, formally educated people tend to have more traditional knowledge, but this is likely linked to the modern technologies (online survey and social media platforms) used to collect data during the COVID-19 pandemic. We suggest that traditional knowledge that has sustained life for centuries in rural communities must be integrated into water resource management to address water scarcity issues in rural Africa.

Keywords Water scarcity - Traditional water conservation technologies $\cdot$ Eastern Cape $\cdot$ South Africa

\section{Introduction}

Water scarcity is one of the pressing environmental issues in the twenty-first century and is presently one of the most prominent risks to the environment, human wellbeing, and socio-economic development (IDRC, 2002; Inkani, 2015). Despite numerous development programs that have been set for decades to 
alleviate water scarcity in the Global South, many people still lack access to water (Birkenholtz, 2013; Olagunju et al., 2019; Ray, 2007; Tekken \& Kropp, 2012; Yazdanpanah et al., 2013). Unfortunately, several factors are exacerbating water scarcity, including the unprecedented impacts of climate change, poor socio-economic development, tremendous population growth, degradation of water resources, and water unavailability (Hanasaki et al., 2013; Schewe et al., 2014; Shen et al., 2014; Wada et al., 2011; Tabane, 2017). In terms of water unavailability, although water is an abundant resource around the globe, much of it is not directly available to address human and environmental needs (Mancosu et al., 2015). The supply of freshwater varies over time, and freshwater resources are unevenly distributed in the world (Veldkamp et al., 2017). As a result, only $10 \%$ of freshwater available worldwide is utilized (Hanasaki et al., 2013; Kummu et al., 2014; Mekonnen \& Hoekstra, 2016).

The impacts of water scarcity include food shortages due to crop failure and economic losses. This makes water scarcity one of the three environmental global threats now and in the future (Veldkamp et al., 2017). People who are expected to be more vulnerable to the impacts of water scarcity are those living in disadvantaged rural areas (Kabeer, 2016). For example, there are nearly 1 billion people in Africa who are already faced with water scarcity (Revenga \& Cassar, 2002). Furthermore, the situation is likely going to get worse in the long run due to increasing water demand and a decline in water availability (Hussain et al., 2019). Moreover, an estimated 700 million people is expected to be displaced in the world because of the impacts of water scarcity if nothing is done to change the status quo (Hameeteman, 2013). Furthermore, if there is no intervention, about 4 billion people in the world would be affected by severe water scarcity at least once a month (Mekonnen \& Hoekstra, 2016). Currently, half of the global population is in communities that are already affected by water scarcity, and under the business-as-usual scenario, the number would increase to 5-6 billion by 2050 (UN, 2018). Also, an estimated number of 5 billion people could be subjected to water shortages by 2050 due to unprecedented impacts of climate change, increased demand, and polluted supplies (UN, 2018). It is also predicted that poor and disadvantaged populations would be more affected, further intensifying already-rising inequalities (UN, 2019). Although the water crisis is global, African countries, in general, are experiencing the worst scenario of the crisis (economic water scarcity).

Addressing water scarcity is a growing challenge in the global community, predominantly in rural areas, where the majority of people heavily relies on rainfed agriculture for their livelihoods (UN, 2018; Gosling \& Arnell, 2016; Mekonnen \& Hoekstra, 2016; Singh et al., 2018). To deal with this problem, the global community in 2015 committed to the United Nations (UN) Sustainable Development Goals (SDGs), of which Goal 6, which provides for clean water and sanitation, promises that by 2030 everyone must have a safe supply of water to meet their needs (Al-Batsh et al., 2019). Despite the significant progress over the past 5 years, this goal seems to be unreachable for most of the world's population with approximately 2.1 billion people, that is, 3 out of 10 individuals, still lack adequate and secure drinking water, whereas 4.5 billion people or 6 in 10 individuals have no legitimately managed sanitation facilities (UN, 2018). This clearly indicates that the world is still far behind in achieving this goal. Furthermore, despite the new development in terms of water supply and sanitation being put in place, it will be a challenge to achieve sustainable development in the rural areas if the renewable freshwater in form of ground and surface water is in short supply (Mohammed et al., 2016).

Even though it has been realized that water issues are complex issues and require the integration of socio-cultural, financial, engineering, and political solutions, hydrological and engineering aspects are still viewed as the only solution to water problems (MacDonald \& Calow, 2009). Unfortunately, the lack of resources (financial and human resources), capacity, and limited engineering strategies to solve challenges of water management hinder the ability to provide basic water infrastructure in many areas across the world, predominantly in Africa (Kyessi, 2005; Mukheibir, 2007). To make SDG No. 6 a reality and address water scarcity, there is a need to integrate both non-conventional (e.g., desalinated water and treated wastewater) and conventional water resources (e.g., groundwater, springs, and flash floods), primarily in areas where water resources are scarce (Al-Batsh et al., 2019). From this perspective, 
it is important to regard rainwater harvest as a vital alternative of water supply in rural areas (Kim et al., 2005; Lopes et al., 2017; Van Roon, 2007; Villarreal \& Dixon, 2005).

Water resource management needs to integrate non-conventional resource to reduce the pressure on conventional sources and protect the environment while addressing water scarcity (Al-Batsh et al., 2019; Fletcher et al., 2008; Van Mechelen et al., 2015). Before modern technologies were introduced, the sources of water included public wells and springs. The management of these sources was determined by local customs to satisfy people's need for water (Oweis et al., 2004; Mekonnen et al., 2021; Petzold et al., 2020). As such, modern technologies alone cannot be the sole solution to global environmental problems like water scarcity. Addressing water scarcity by introducing only modern technologies while neglecting traditional technology is not an effective solution for people who depend on traditional practices (Behailu et al., 2016).

In light of this background, a solution to sustainable water resource management in the future will be in the form of re-valuation and rediscovery of traditional knowledge and technologies (UNESCO, 2012). Traditional technologies are water harvesting systems for collecting, storing, and conserving surface water run-off (Bhattacharya, 2015). Traditional technologies for water sources are the knowledge and technology that people in a specific culture or society have established over time and continue to develop (Mbilinyi et al., 2005). This suggests that traditional technologies of water conservation should be given priority and revived as a sustainable alternative for water supply as well as for integrated development in the context of persistent calls for modernization. Traditional knowledge is a resource that should be conserved not only as a culture's identity or for tourism but also be used to address real-life challenges (Leonard et al., 2013).

The present project aims, firstly, to document the diversity of traditional water conservation technologies and inherent challenges and successes. We also aim to identify the determinants of the traditional knowledge of these technologies, including how they vary from city to rural areas in the Eastern Cape province of South Africa.

\section{Materials and methods}

Study area

The study was conducted in the Eastern Cape Province (Fig. 1a) which is the second-largest province in South Africa. It covers an area of $169000 \mathrm{~km} 2$ and occupies $13.9 \%$ of South Africa's land area. The Eastern Cape is located at $32.2968^{\circ} \mathrm{S}, 26.4194^{\circ} \mathrm{E}$, between the KwaZulu-Natal (KZN) and the Western Cape (WC) provinces. The province is bordered by the Indian Ocean on its southern and eastern parts. The province consists of two metropolitan municipalities (Nelson Mandela Bay and Buffalo City), six district municipalities (Fig. 1b), and 37 local municipalities (Fig. 1c).

The province has a population of 6,7 million people, which is close to $13.5 \%$ of the total population of South Africa (Hamann \& Tuinder, 2012; Jordaan et al., 2019). The population increased by $6.6 \%$ between 2011 and 2016, i.e., from 6562053 in 2011 to 6996976 in 2016 (Eastern Cape Community Survey, 2018). The most dominant ethnic group is black African, which makes up to $88.3 \%$ of the population, followed by coloured (8.3\%), white (4.7\%), and Asian $(0.4 \%)$.

The Eastern Cape has a diverse climate because it is located between subtropical conditions of KZN and the Mediterranean climate conditions of the Western Cape province of South Africa. The Karoo on the western side of the province experiences hot summers and moderate winters, while coastal areas experience mild-warm temperatures (Hamman \& Tuinder, 2012). The rainfall in inland regions varies between 400 and $800 \mathrm{~mm}$. In the western part of the province, the rainfall varies from $1000 \mathrm{~mm}$ to less than $200 \mathrm{~mm}$ in the Karoo. The eastern regions receive more than $800 \mathrm{~mm}$ annually with $1200 \mathrm{~mm}$ at the coastal zones and $600 \mathrm{~mm}$ in some areas of the central part (Jordaan et al., 2019). The average temperatures range from $18{ }^{\circ} \mathrm{C}$ in July to $25.5^{\circ} \mathrm{C}$ in February. The mean minimum temperature varies from 14.3 to $19.8{ }^{\circ} \mathrm{C}$ in January and from 1.8 to $13.4{ }^{\circ} \mathrm{C}$ in July to a mean maximum of $14.3-25.3{ }^{\circ} \mathrm{C}$ in January and 19.5-21.4 ${ }^{\circ} \mathrm{C}$ in July (Mdoda, 2015).

The Geology of the Eastern Cape is dominated by younger sedimentary rocks, predominantly clay, or sand based (Mepaiyeda et al., 2020). Coal seams 


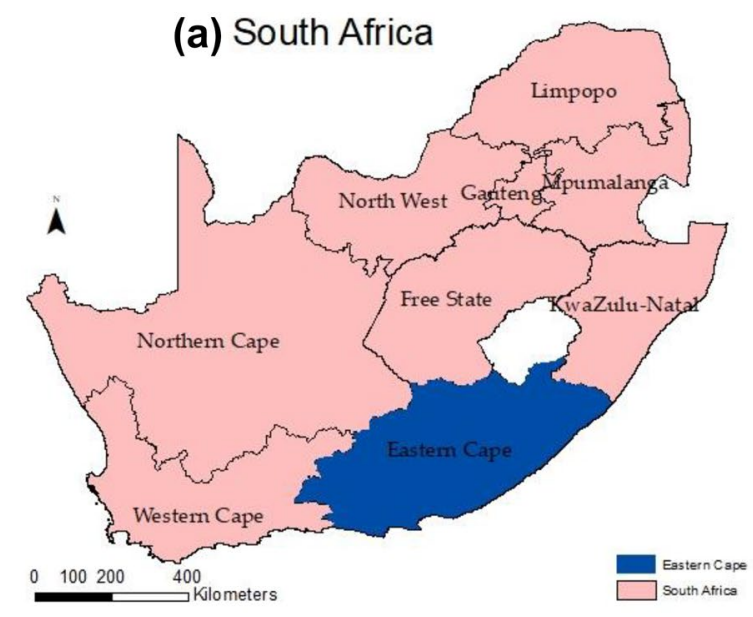

\section{(b) District Municipalities}

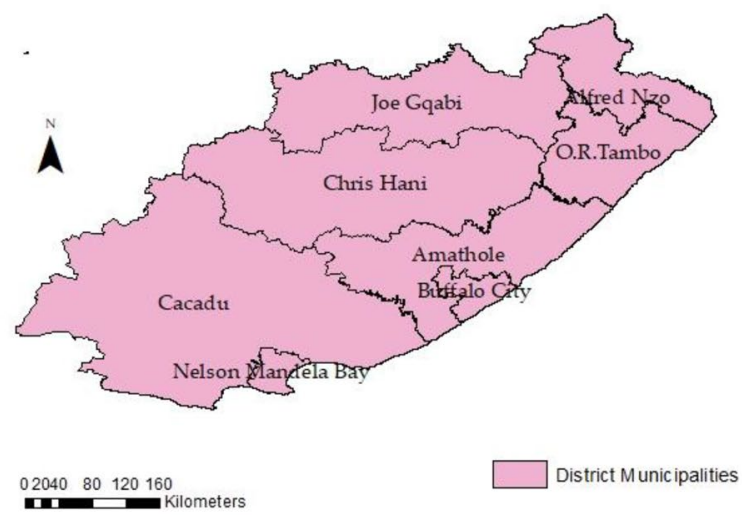

\section{(c) Local Municipalities}

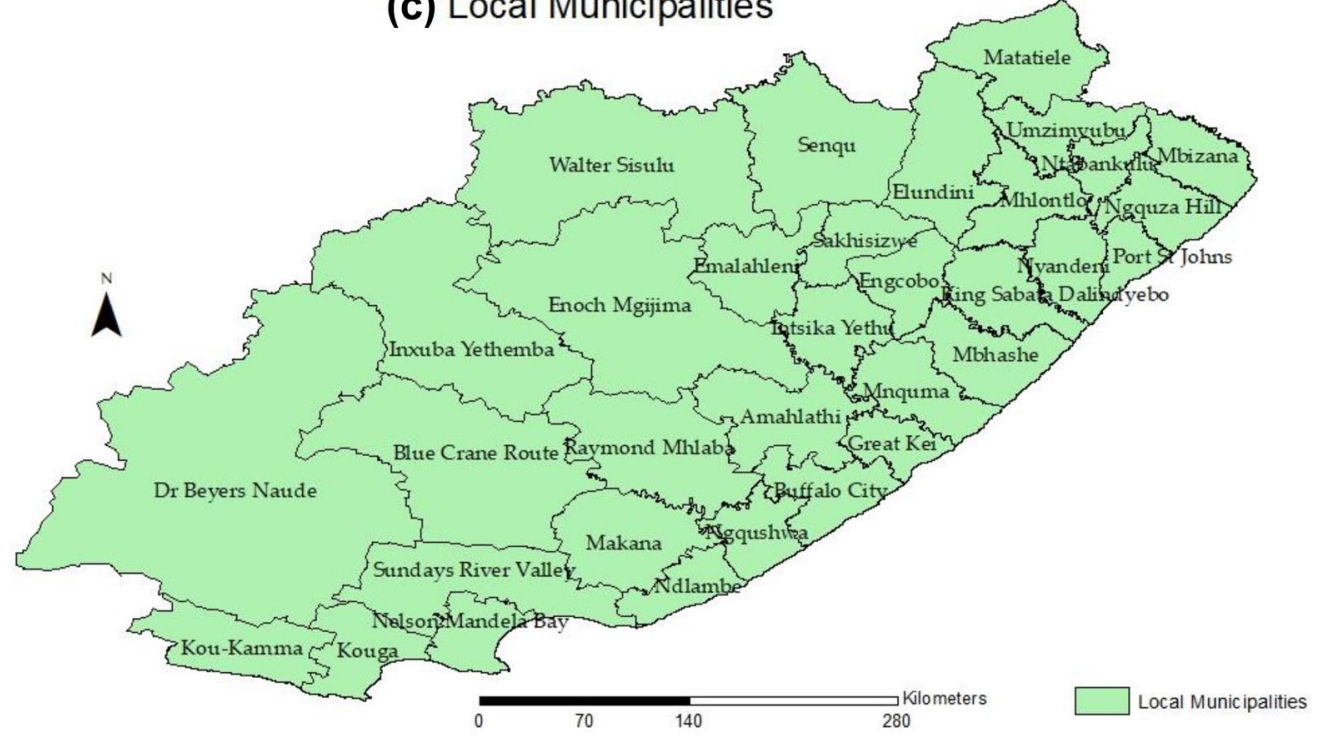

Fig. 1 Location of Eastern Cape in South Africa and district and local municipalities of the Eastern Cape Province

found in the Eastern Cape are predominantly narrow and of poor grade, although some mining activities occur in the region.

While a third of South Africa receives sufficient rain for crop production, only approximately $12 \%$ of the country has fertile soils. Most of this is marginal for crop production, and less than 3\% of South Africa is considered as high-potential land. In the Eastern Cape Province, there is high potential agricultural land in the OR Tambo district and low potential Karoo in Cacadu (Jordaan et al., 2019). The coastal areas to the north of the East London city is characterized by short and deeply incised rivers flowing parallel to each other out to sea (Hamann \& Tuinder, 2012).

\section{Data collection}

Data were collected in 18 villages/cities geographically distributed along a southward axis (Fig. 2). This geography allows us to analyse the changes in people's knowledge of traditional water technologies from north to south. Figure 2 shows not only the geographic 


\section{Geographic Distribution of Respondents}

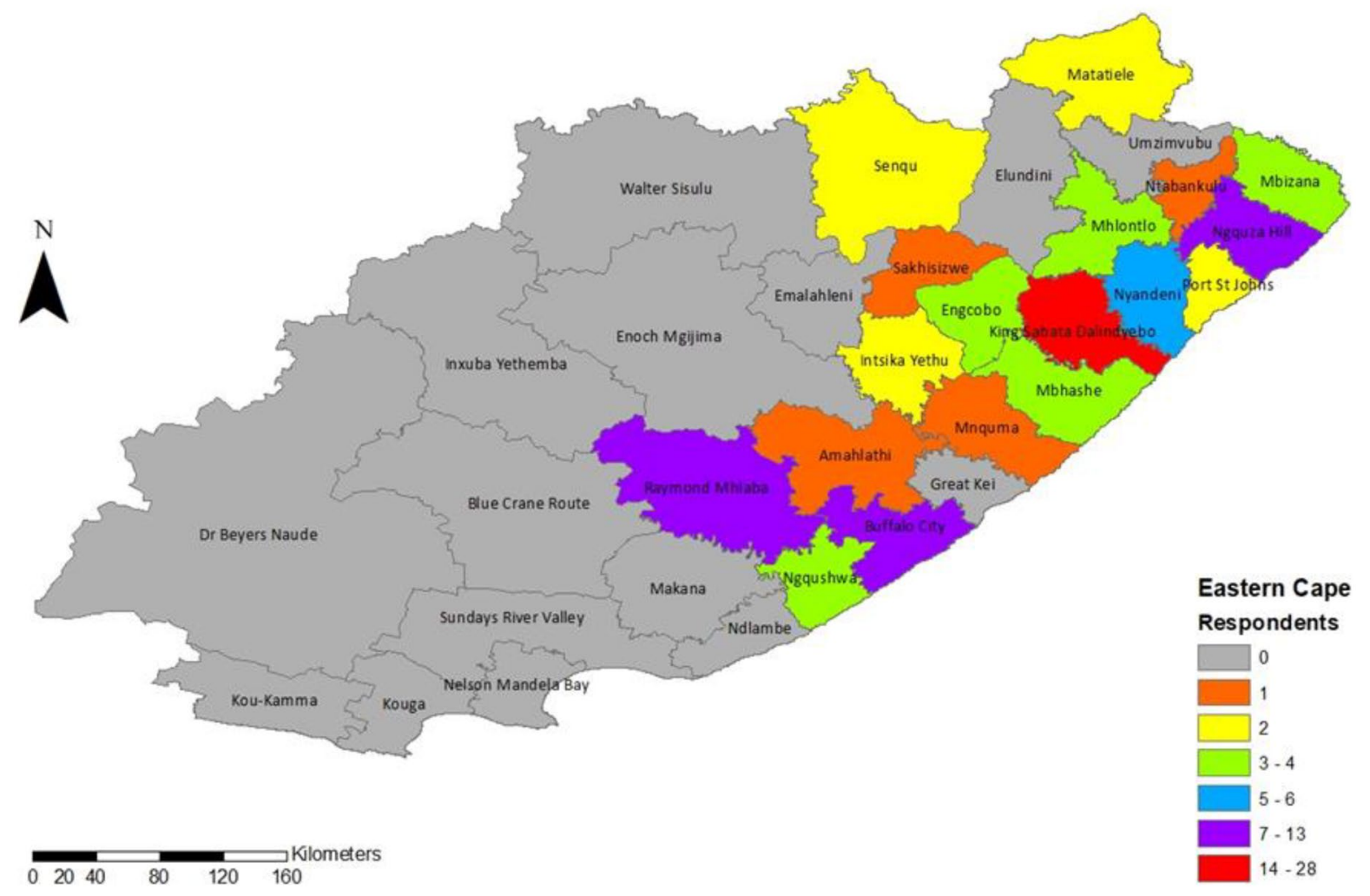

Fig. 2 Geographical pattern of selected villages for data collection in the Eastern Cape province

location of all the 18 villages/cities that participated in the study but also the number of respondents (1-18 people) per village/city. In total, 93 people voluntarily decided to respond to our questionnaires. Data for the study were collected (see data in Supplemental Information) in two phases determined by the COVID-19 lockdown regulations.

During the first phase, we conducted site visits in Nxaruni village under Buffalo City Municipality and Ncera under Raymond Mhlaba Municipality, before the lockdown, and 13 respondents were interviewed in each village. Participants were purposively selected, and elderly people, males and females, were the most targeted (Yineger et al., 2008) on the basis that traditional knowledge increases with age. The second phase of data collection was done online when the COVID-19 regulations were enforced, preventing us from furthering our site visits. An online questionnaire was created using Google documents, and the online link of the questionnaire was made available to the public in the study area through social media platforms and emails.

The questionnaire was designed into two sections. The first section was mainly meant to gather the demographic profile of respondents, and questions asked were related to age, gender, and locations or origins of the respondents. The second section aimed to document people's knowledge of the traditional technologies of water conservation in Eastern Cape. In this section, questions were designed such that we can document the interventions provided by the government or any other institution as well as successes and challenges faced by local communities using water traditional technologies. Part of this section also included questions formulated to document water conservation strategies used by respondents and their primary sources of water. Free listing was required in section two of the questionnaire where respondents 
were asked to list the technologies of water conservation that they know. In total, 93 people responded to our questionnaire (see Supplemental Information).

\section{Data analysis}

The study generated both qualitative and quantitative data (mixed methodology approach). All quantitative analyses were done in $\mathrm{R}$ ( $\mathrm{R}$ Development Core Team, 2017).

Qualitative data analysis consisted of summarizing people's traditional knowledge in a form of a table. These knowledge concern the traditional water conservation technologies as well as challenges and successes inherent to the use of these technologies.

Quantitative data analysis consisted of model fitting. Prior to model fitting, data were coded as follows. For example, education levels were coded as the minimum number of years one has to spend in school for a particular degree: 12 years (for Matric, i.e., end of high school), 15 years (BSc), 17 (MSc), etc. To estimate how far is the location of a respondent, the distance of his/her location was estimated from two reference localities, one is Port Elizabeth (the most urbanized locality in the Eastern Cape) and the other one is Ngqushwa, a rural locality in the southern part of the province (Fig. 2). Each locality was selected such that when moving away from Port Elizabeth (urban reference), the level of rurality increases and when moving away from ngqushwa (rural reference), the level of urbanization increases.

To test how traditional knowledge of these technologies vary along city-rural axis in the Eastern Cape province, a generalized linear model (GLM) was fitted to the data collected with a Poisson error structure, given that the variable "knowledge" is a count data (number of traditional technology free-listed by a respondent). The model was fitted in $\mathrm{R}$ as follows: " $\mathrm{glm}(\mathrm{y} \sim \mathrm{x}$, family= "poisson",data)" where " $y$ " is the knowledge of traditional water technologies; " $x$ " is the socioeconomic variables such as geographic distance of residents' location to reference point (Port Elizabeth or ngqushwa), gender, and level of education; and "data" is the excel sheet where all variables are found. In the model, the number of traditional technologies free-listed by respondents during the interview was used as a proxy of their knowledge of traditional technologies. This knowledge (number of freely listed traditional technologies) was used as a response variable, while education level, gender, age of respondents, locality of origins of the respondents, and geographic distance between each locality and a reference locality (Port Elizabeth and Ngqushwa) were used as predictive variables.

\section{Results}

Diversity of traditional water conservation technologies

In total, 10 different types of traditional technologies of water conservation have been identified in this study, e.g., Nkgo, Ingqayi, traditional water tanks, and drum system (Table 1). However, the number of technologies reported varies from 1 to 8 depending on the municipality, although the "traditional water tank" (Fig. 3a) is shared across municipalities. The number of most cited technology increases when moving southward from the city of Port Elizabeth. Another common system is the drum system (Fig. 3b).

\section{Determinants of traditional knowledge}

The results of model fitting show a positive and significant relationship between traditional knowledge and geographic distance when using Port Elizabeth city as reference $(\beta=0.002 \pm 0.0008 ; P=0.004)$, suggesting that traditional knowledge of water conservation increases when moving away from the city towards rural areas. Also, there is a positive and significant relationship between geographic location and knowledge $(\beta=0.002 \pm 0.0009 ; P=0.008)$ when using Ngqushwa village as reference, suggesting that traditional knowledge of water conservation increases when moving away from Ngqushwa. In addition, we found that traditional knowledge does not depend on gender $(\beta=0.162 \pm 0.259 ; P=0.53)$ neither does it depend on age $(\beta=0.07 \pm 0.14 ; P=0.64)$. However, it does depend on the level of education $(\beta=1.121 \pm 0.3405$; $P<0.001)$. A summary of the correlation between traditional knowledge and socio-demographic variables is shown in Table 2. 
Table 1 Traditional technologies of water conservation used in the Eastern Cape Province

\begin{tabular}{|c|c|c|c|c|c|}
\hline Municipality & $\begin{array}{l}\text { Geographic location } \\
\text { of the municipality }\end{array}$ & Technologies reported & $\begin{array}{l}\text { Is the system still in } \\
\text { use today? }\end{array}$ & $\begin{array}{l}\text { Number } \\
\text { of technologies } \\
\text { Reported }\end{array}$ & $\begin{array}{l}\text { Most frequently cited } \\
\text { technology in each } \\
\text { municipality }\end{array}$ \\
\hline Matatiele & - North & - Nkgo & - No longer used & 1 & Nkgo $(100 \%)$ \\
\hline Mbizana & - North & $\begin{array}{l}\text { - Traditional storage } \\
\text { tanks } \\
\text { - Drums }\end{array}$ & $\begin{array}{l}\text { - Moderately used } \\
\text { - Moderately used }\end{array}$ & 2 & $\begin{array}{l}\text { Traditional storage } \\
\text { tanks }(100 \%)\end{array}$ \\
\hline Ngquza Hill & - North & $\begin{array}{l}\text { - Drip irrigation } \\
\text { - Drum system } \\
\text { - Traditional storage } \\
\text { tanks }\end{array}$ & $\begin{array}{l}\text { - Frequently used } \\
\text { - Frequently used } \\
\text { - Frequently used }\end{array}$ & 3 & $\begin{array}{l}\text { Traditional storage } \\
\text { tanks }(57 \%)\end{array}$ \\
\hline Mhlontlo & - North & $\begin{array}{l}\text { - Traditional storage } \\
\text { tanks } \\
\text { - Drum system }\end{array}$ & $\begin{array}{l}\text { - Frequently used } \\
\text { - Frequently used }\end{array}$ & 1 & $\begin{array}{l}\text { Traditional storage } \\
\text { tanks and drum } \\
\text { system (50\% } \\
\text { respectively) }\end{array}$ \\
\hline Port St Johns & - North & $\begin{array}{l}\text { - Traditional storage } \\
\text { tanks }\end{array}$ & - Frequently used & 1 & $\begin{array}{l}\text { Traditional storage } \\
\text { tanks }(100 \%)\end{array}$ \\
\hline Nyandeni & - North & $\begin{array}{l}\text { - Dam construction } \\
\text { - Drip irrigation } \\
\text { - Traditional storage } \\
\text { tanks }\end{array}$ & $\begin{array}{l}\text { - Frequently used } \\
\text { - Frequently used } \\
\text { - Frequently used }\end{array}$ & 3 & $\begin{array}{l}\text { Dam construction } \\
\quad(50 \%)\end{array}$ \\
\hline $\begin{array}{l}\text { King Sabata } \\
\text { Dalindyebo }\end{array}$ & - Centre & $\begin{array}{l}\text { - Traditional irriga- } \\
\text { tion cans } \\
\text { - Drip irrigation } \\
\text { - Ingqayi } \\
\text { - Traditional storage } \\
\text { tanks } \\
\text { - Contour ploughing } \\
\text { - Dam construction } \\
\text { - Ipitsi }\end{array}$ & $\begin{array}{l}\text { - Frequently used } \\
\text { - Frequently used } \\
\text { - No longer used } \\
\text { - Moderately used } \\
\text { - Frequently used } \\
\text { - Rarely used } \\
\text { - No longer used }\end{array}$ & 7 & $\begin{array}{l}\text { Traditional storage } \\
\text { tanks }(43 \%)\end{array}$ \\
\hline Sakhisizwe & - Centre & $\begin{array}{l}\text { - Traditional storage } \\
\text { tanks } \\
\text { - Drum systems }\end{array}$ & $\begin{array}{l}\text { - Frequently used } \\
\text { - Rarely used }\end{array}$ & 2 & Drum system (100\%) \\
\hline Engcobo & - Centre & $\begin{array}{l}\text { - Traditional storage } \\
\text { tanks }\end{array}$ & - Frequently used & 1 & $\begin{array}{l}\text { Traditional storage } \\
\text { tanks }(100 \%)\end{array}$ \\
\hline Mbhashe & - Centre & $\begin{array}{l}\text { - Traditional storage } \\
\text { tanks } \\
\text { - Construction of } \\
\text { dams }\end{array}$ & $\begin{array}{l}\text { - No longer used } \\
\text { - Frequently used }\end{array}$ & 2 & $\begin{array}{l}\text { Traditional storage } \\
\text { tanks }(100 \%)\end{array}$ \\
\hline Mnquma & - South & $\begin{array}{l}\text { - Traditional storage } \\
\text { tanks }\end{array}$ & - No longer used & 1 & $\begin{array}{l}\text { Traditional storage } \\
\text { tanks }(100 \%)\end{array}$ \\
\hline Raymond Mhlaba & - South & $\begin{array}{l}\text { - Traditional storage } \\
\text { tanks }\end{array}$ & $\begin{array}{l}\text { - No longer used } \\
\text { - No longer used }\end{array}$ & 1 & $\begin{array}{l}\text { Traditional storage } \\
\text { tanks }(100 \%)\end{array}$ \\
\hline Buffalo City & - South & $\begin{array}{l}\text { - Traditional storage } \\
\text { tanks } \\
\text { - Contour ploughing }\end{array}$ & $\begin{array}{l}\text { - No longer used } \\
\text { - Frequently used }\end{array}$ & 2 & $\begin{array}{l}\text { Contour ploughing } \\
(66 \%)\end{array}$ \\
\hline Ngqushwa & - South & $\begin{array}{l}\text { - Traditional storage } \\
\text { tanks }\end{array}$ & - Frequently used & 1 & $\begin{array}{l}\text { Traditional storage } \\
\text { tanks }(100 \%)\end{array}$ \\
\hline
\end{tabular}


a

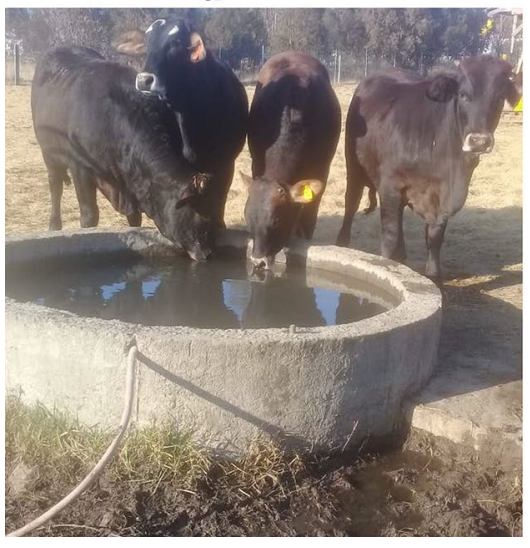

b

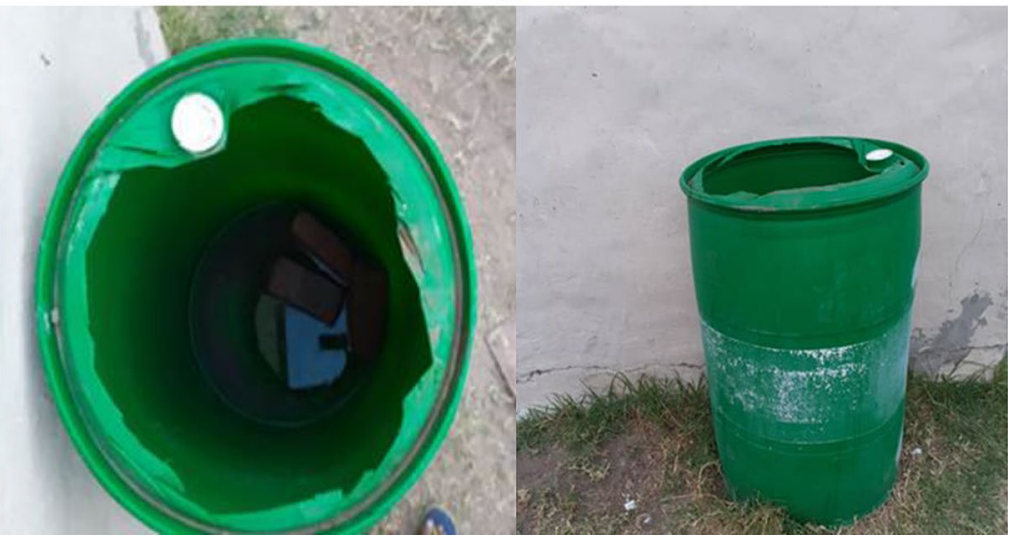

Fig. 3 Some of the traditional water conservation technologies recorded in the present study. a Traditional water tank (picture supplied by Mr Mhlongo); b drum system positioned under the

\section{Discussion}

Diversity of traditional knowledge of water conservation technologies

Traditional technologies of rainwater conservation have been used by different communities in the Eastern Cape province. The implementation of these technologies varies with location and cultural practices. Interestingly, some municipalities reported similar technologies which could be attributed to similar cultural practices. The diversity of technologies reported is discussed below.

\section{Ipitsi}

Ipitsi is a shallow excavated piece of land that is developed by indigenous communities for surface and groundwater harvesting. This technology has been recorded

Table 2 Summary of the coefficients of the correlation tests between traditional knowledge of water conservation and sociodemographic variables. Distance_PE = distance of the location of a respondent from Port Elizabeth, the most urbanized loca- rooftop(right) and drum system in a dry period (left) (picture supplied by Mr. Myataza)

in parts of the King Sabata Dalindyebo Local Municipality. This system is developed in communities where groundwater is at a shallow depth, which allows indigenous people to dig easily for water harvesting. Water is collected by tying bucket handles with a rope for groundwater harvesting. Findings of this study suggest that this system has declined in use. A number of reasons could explain the decline. First, it could be because the government is investing in modern groundwater development in rural communities, with no consideration of this traditional technique. Another reason is that this technique is not safe (dug holes not covered) and therefore dangerous to users (Denison \& Wotshela, 2009). As modern technologies were introduced, the communities that previously depended on ipitsi for water supply shifted to the new technologies of water supply. In doing so, these communities abandoned ipitsi and depended on the newly introduced modern technologies.

tion in the south of the province; Distance_Ngqushwa=distance from Ngqushwa, one rural location in the south of the province

\begin{tabular}{lcccc}
\hline Variables & Estimate & Std. error & $z$ value & $p$ value \\
\hline DISTANCE_PE & 0.0027 & 0.0008 & 2.873 & 0.004 \\
DISTANCE_NGQUSHWA & 0.0024 & 0.0009 & 2.647 & 0.008 \\
GENDER_M & 0.1623 & 0.2589 & 0.627 & 0.530 \\
AGE & -0.0067 & 0.0144 & -0.468 & 0.64 \\
EDUCATION_LEVEL & 1.1213 & 0.3405 & 3.293 & $<0.0001$ \\
\hline
\end{tabular}


Traditional storage tanks

The traditional storage tanks are man-made tanks that are traditionally designed to capture runoff and groundwater in some instances (Fig. 3a). The storage tanks can store enough water for household consumption until the next rain season. In some areas of the Eastern Cape, the respondents provided that storage tanks are not the primary rainwater harvesting system but are used to supplement water sources during periods of water scarcity. Similar studies indicate that rural communities have always developed storage tanks for collecting rainwater including countries like Kenya and India (Aroka, 2010; Saxena, 2017). Although this technology is the most commonly cited in the province, evidence from this study shows that this technique is already diminishing in many parts of the province including Engcobo, Mbizana, and Ngquza Hill communities. This technology, because of its limitations such as water quality concerns, is now becoming obsolete and is being replaced by modern tanks which also collect rainwater from rooftops for domestic purposes.

\section{Drums}

Another rooftop catchment technology is the drum system. Drums are made of plastic and metal and normally used to deliver goods to the markets and end up in the public and used for collection and rainwater harvesting. Drums are local systems that are positioned under the rooftop and store rainwater which is mainly used for drinking purposes. The amount of water collected by the rooftop catchment systems heavily depend on the size of the storage system. Bigger storage tanks and drums can harvest and store enough water for household consumption, while smaller sizes can lead to insufficient quantities of water for household demand. In instances, where the collected quantities of water are not enough to meet household water demands, the respondents provided that they search for alternative sources such as collecting water from nearby rivers.

\section{Clay pots}

A clay pot is a circular traditional water storage pot made from clay. Clay pots in this study were commonly found in different parts of the Eastern Cape and are commonly known as Nkgo in Sotho tribe (one of the ethnic groups in South Africa) in Matatiele and Ingqayi in Xhosa communities (an ethnic group in South Africa). The results of this study may suggest that clay pots are used for drinking water; however, similar studies discovered that clay pots have been used as a traditional system of irrigation alternative to drip method (Adhikary \& Pal, 2020). Although this has been an efficient technology to keep drinking water fresh and cold for the indigenous communities, evidence from this study show that the technology is no longer used in parts of the King Sabata Dalindyebo Local Municipality.

\section{Construction of dams}

Construction of dams is a community-based traditional technique of water storage which is not only essential for rainwater harvesting but is an indigenous technique of disaster risk management such as flood control. Traditional communities in the Eastern Cape create dams in open spaces to collect surface runoff and rainwater which is stored and used during dry seasons. Water harvested in dams is used for domestic and for irrigation purposes in some instances. These dams are usually small and used for irrigation. This system has also been widely used in Indian communities for water harvesting (Church et al., 2015).

\section{Contouring}

Contour ploughing is a traditional technique of both water and soil conservation. This is done by ploughing against the slope to capture surface runoff and prevent soil erosion. It is widely practiced by smallscale farmers. This is an important indigenous technique as it reduces the need for water collection for irrigation of crops. Other studies suggest that this technique has been used in countries like Brazil to control and revert the problems caused by soil erosion (Telles et al., 2019). Similar studies also provide that this technique reduces runoff and improves 319 crop yields through soil moisture and retention (Farahani et al., 2016).

\section{Drip irrigation system}

Drip irrigation is an indigenous technology that is used in areas of King Sabata Dalindyebo and Ngquza Hill 
local municipalities. This system operates by transporting water from a catchment directly to the crops through pipes and sometimes with clay pots, buckets, and reused containers. To reduce the water needed for irrigation, indigenous communities irrigate twice a day, before the sunrise and after the sunset. These traditional irrigation technologies have been criticized for not enabling large scale farming practices and failing during devastating droughts (Kumar \& Pandit, 2018).

\section{Determinants of traditional knowledge}

\section{Geographic location and traditional knowledge}

The results of this study reveal a positive correlation between geographic distance and knowledge of water conservation, suggesting that traditional knowledge of water conservation increases when moving from major cities to rural towns $(\beta=0.002 \pm 0.0008 ; P=0.004)$. The major cities of the province are the most developed as compared to the rural towns when moving up north. Studies show that wealthy communities tend to be densely populated with greater infrastructure development (Paniagua-Zambrana et al., 2014). This study agrees with other studies that provide that traditional knowledge in major cities tend to be abandoned as it no longer fits into current ways of doing things (ReyesGarcía et al., 2013). A loss of traditional knowledge in major cities is also due to the availability of alternative opportunities (Paniagua-Zambrana et al., 2014).

\section{Gender and traditional knowledge}

Recent studies provide that gender issues emerge to be of particular importance in traditional ecological knowledge (Malesu et al., 2006). The results of this study showed that there is no correlation between traditional knowledge of water conservation and gender $(\beta=0.162 \pm 0.259 ; P=0.53)$. This finding was inconsistent with a series of other studies, which provide that woman have greater traditional knowledge than men (Quinlan \& Quinlan, 2007; Voeks \& Leony, 2004). Women are often recognized as controllers of traditional knowledge linked to the management of natural resources (Howard, 2003). Several studies also assert that women have a strong interest in environmental conservation, hence the strong traditional knowledge compared to men (Gutierrez-Montes et al., 2012; Montanari \& Bergh, 2019). Contrary to this, other studies indicate that men have more traditional knowledge than women, due to the division of labour and domestic responsibilities (Byg \& Balslev, 2004). In the meantime, other studies suggest that the prevailing impacts of water scarcity have forced both men and women to be involved in the development and use of traditional rainwater harvesting systems (ATPS, 2013), which most likely is the reason why the present study did not find any difference in the knowledge of men vs. women.

\section{Age and traditional knowledge}

The results support the notion that traditional knowledge is not influenced by age. These results are inconsistent with a large number of existing studies in the broader literature. The existing studies in countries like Brazil provide that elder tend to have greater traditional knowledge than young people (Merétika et al., 2010; Weckmüller et al., 2019). Similar studies that also discovered that there is no correlation between age and traditional knowledge and that older people are 370 not experts with much greater knowledge than younger people (Paniagua-Zambrana et al., 2014) as found too in the present study. This is explained by the fact that traditional knowledge is part of a tradition and is passed from one generation to the next through storytelling, crafts, ceremonies, and other methods (Fin et al., 2017). These studies support the pattern of results of this study and suggest perhaps that there is an ongoing process of transmission of traditional knowledge (Zambrana et al., 2007; Godoy et al., 2001). Moreover, the literature indicates that the acquisition of indigenous skills occurs before the age of 15 and therefore greater life experience of elders cannot be a determinant of traditional knowledge (Hunn, 2002). The results of this study tie well with a study that reported the determinants of local ecological knowledge, which indicated that oldest generation did not show the highest levels of knowledge as compared to the younger generation (Iniesta-Arandia et al., 2015).

\section{Education and traditional knowledge}

The expectation here is that well-educated people would have less knowledge of traditional technologies than less-educated people (Behailu et al., 2016; Weckmüller 
et al., 2019). This is because well-educated people mostly live in cities and have left rural areas very long ago. Although some of them may be returning from time to time to villages, they do not interact more frequently with those traditional technologies as compared to people based in rural areas. As a result, they are expected to remember less of traditional technologies of water conservation in rural areas. As opposed to this expectation, the study shows that well-educated people tend to know more than people in rural areas. This may not be a surprise for the following reason linked to the data collection approach. Due to COVID-19 lockdown regulations, face-to-face data collections were not possible, and therefore modern technologies were used (e.g., online survey and socio-medias such as WhatsApp and Facebook) to collect data. These modern technologies can only be used by formally educated people living in cities who can read and write, thus engendering some forms of bias in the sampling towards more educated people, resulting in the finding that educated people have more traditional knowledge.

\section{Conclusion}

This study emphasized the need to unlock alternative sources of water using traditional technologies to address water scarcity, particularly for the most vulnerable communities. The objectives of the study were to document the traditional technologies of water conservation in the Eastern Cape Province and to analyse how traditional knowledge of water conservation changes with demographic parameters and geographic distance from urban setup. The diversity of traditional technologies used by rural inhabitants to adapt to water scarcity was documented and they range from rooftop to surface water conservation systems. This study showed that different technologies have been widely used in the rural areas of the Eastern Cape to conserve water and address water scarcity. Interestingly, the results indicated that there is no significant relationship between age or gender and traditional knowledge. This implied that traditional knowledge of water conservation in the Eastern Cape does not depend on gender and age. In addition, the findings showed a significant relationship between locality and traditional knowledge, which implies that traditional knowledge changes with geographic location with more knowledge in rural areas as compared to the cities. There is also a positive relationship between traditional knowledge and education.

Policy recommendations from this study include the integration of traditional water management into water governance, policy, and decision-making in South Africa. This is important considering that South Africa is a water-scarce country that needs alternative sources of water to enhance adaptation and resilience of vulnerable people to water scarcity. There is a need to conduct a water quality study to assess the quality of water harvested from the traditional systems and explore ways in which the size of these technologies can be increased to ensure that enough quantities of water are harvested even during dry periods to improve the effectiveness of traditional systems. The main recommendation of this study is that local government needs to be aware of the importance of local knowledge in water conservation. Traditional knowledge should not be deemed as less important than scientific knowledge as the latter also has potential gaps in addressing water scarcity. Some of the initiatives local governments can take to improve the effectiveness of the traditional systems documented in this study include educating people about various ways of household drinking water treatment. This is particularly important as one of the limitations of traditional water systems includes water quality concerns. Overall, we recommend, following Yazdanpanah et al. (2013), a switch from government business-as-usual approach of water management to appropriate water governance.

Acknowledgements We would like to extend our sincere gratitude to the respondents of the Eastern Cape Province.

\section{Declarations}

Ethics approval The study was approved by the Ethical Committee of the Faculty of Science, University of Johannesburg. The evidence is provided in the Supplemental Information.

Conflict of interest The authors declare no competing interests.

\section{References}

Adhikary, R., \& Pal, A. (2020). Clay Pot Irrigation-A review study. Asian Plant Research Journal, 5(1), 37-42.

African Technology Policy Studies Network (ATPS). (2013). Farmers' perception and adaptive capacity to 
climate change and variability in the upper catchment of Blue Nile, Ethiopia [Bewket Amdu, Azemeraw Ayehu, Andent Deressa], ATPS Working Paper No. 77.

Al-Batsh, N., Al-Khatib, I. A., Ghannam, S., Anayah, F., Jodeh, S., Hanbali, G., et al. (2019). Assessment of rainwater harvesting systems in poor rural communities: A case study from Yatta Area. Palestine Water, 11(3), 585.

Aroka, N. (2010). Rainwater harvesting in Rural Kenya: Reliability in a variable and changing climate. Unpublished MSc thesis. Sweden: Stockholm University.

Behailu, B., Pietilä, P., \& Katko, T. (2016). Indigenous practices of water management for sustainable services: Case of Borana and Konso. Ethiopia. Sage Open, 6(4), 1-11.

Bhattacharya, S. (2015). Traditional water harvesting structures and sustainable water management in India: A socio-hydrological review. International Letters of Natural Sciences, 37, 30-38.

Birkenholtz, T. (2013). On the network, off the map: Developing intervillage and intragender differentiation in rural water supply. Environment and Planning: Society and Space, 31(2), 354-371.

Byg, A., \& Balslev, H. (2004). Factors affecting local knowledge of palms in Nangaritza Valley in South-Eastern Ecuador. Journal of Ethnobiology, 24(2), 255-278.

Church, J., Ekechi, C. O., Hoss, A., \& Larson, A. J. (2015). Tribal water rights: Exploring dam construction in Indian country. The Journal of Law, Medicine \& Ethics, 43(1), 60-63.

Denison, J., \& Wotshela, L. (2009). Indigenous water harvesting and conservation practices: Historical context, cases and implications. Water Research Commission Report No. TT, 392(09).

Eastern Cape Community Survey of 2016. (2018). Provincial profile of Eastern Cape report. Statistics South Africa: Pretoria.

Farahani, S. S., Fard, F. S., \& Asoodar, M. A. (2016). Effects of contour farming on runoff and soil erosion reduction: A review study. Elixir Agriculture, 101, 44089-44093.

Finn, S., Herne, M., \& Castille, D. (2017). The value of traditional ecological knowledge for the environmental health sciences and biomedical research. Environmental health perspectives, 125(8), 085006.

Fletcher, T. D., Deletic, A., Mitchell, V. G., \& Hatt, B. E. (2008). Reuse of urban runoff in Australia: A review of recent advances and remaining challenges. Journal of Environmental Quality, 37(S5), S-116.

Godoy, R., \& Contreras, M. (2001). A comparative study of education and tropical deforestation among lowland Bolivian Amerindians: Forest values, environmental externality, and school subsidies. Economic Development and Cultural Change, 49(3), 555-574.

Gosling, S. N., \& Arnell, N. W. (2016). A global assessment of the impact of climate change on water scarcity. Climatic Change, 134(3), 371-385.

Gutierrez-Montes, I., Emery, M., \& Fernandez-Baca, E. (2012). Why gender matters to ecological management and poverty reduction. In Integrating Ecology and Poverty Reduction. Springer, New York, NY.

Hamann, M., \& Tuinder, V. (2012). Introducing the Eastern Cape: A quick guide to its history, diversity and future challenges. Stockholm Resilience Centre, Stockholm University.
Hameeteman, E. (2013). Future water (In)security: Facts, figures, and predictions. Global water institute.

Hanasaki, N., Fujimori, S., Yamamoto, T., Yoshikawa, S., Masaki, Y., Hijioka, Y., Kainuma, M., Kanamori, Y., Masui, T., Takahashi, K., \& Kanae, S. (2013). A global water scarcity assessment under shared socio-economic pathways-Part 2: Water availability and scarcity. Hydrology and Earth System Sciences, 17(7), 2393-2413.

Howard, P. (2003). The major importance of 'minor' resources: Women and plant biodiversity. London, UK: International Institute for Environment and Development (IIED).

Hunn, E. S. (2002). Evidence for the precocious acquisition of plant knowledge by Zapotec children. Ethnobiology and Biocultural Diversity, 604, 13.

Hussain, F., Hussain, R., Wu, R. S., \& Abbas, T. (2019). Rainwater harvesting potential and utilization for artificial recharge of groundwater using recharge wells. Processes, $7(9), 623$.

IDRC (International Development Research Council). (2002). In focus: Water-local level management. IDRC, Canada IDWSSD, 1981 to 1990) in the Niger Delta Region of Nigeria. http://www.springerlink.com/content/ 1bn488q22074k234/fulltext.pdf. Accessed 09 June 2019

Inkani, A. (2015). Households' vulnerability and adaptation to water scarcity in rural areas Katsina State, Nigeria. Unpublished Dissertation for Doctor Of Philosophy degree In Geography. University of Nairobi.

Iniesta-Arandia, I., Del Amo, D. G., García-Nieto, A. P., Pineiro, C., Montes, C., \& Martín-López, B. (2015). Factors influencing local ecological knowledge maintenance in Mediterranean watersheds: Insights for environmental policies. Ambio, 44(4), 285-296.

Jordaan, A., Bahta, Y. T., \& Phatudi-Mphahlele, B. (2019). Ecological vulnerability indicators to drought: Case of communal farmers in Eastern Cape, South Africa. Jàmbá: Journal of Disaster Risk Studies, 11(1), 1-11.

Kabeer, N. (2016). Leaving no one behind: The challenge of intersecting inequalities. ISSC, IDS and UNESCO, Challenging Inequalities: Pathways to a Just World, World Social Science Report, 55-8.

Kim, R. H., Lee, S., Kim, Y. M., Lee, J. H., Kim, S. K., \& Kim, S. G. (2005). Pollutants in rainwater runoff in Korea: Their impacts on rainwater utilization. Environmental Technology, 26(4), 411-420.

Kumar, M. D., \& Pandit, C. M. (2018). India's water management debate: Is the 'civil society' making it everlasting? International Journal of Water Resources Development, 34(1), 28-41.

Kummu, M., Gerten, D., Heinke, J., Konzmann, M., \& Varis, O. (2014). Climate-driven interannual variability of water scarcity in food production potential: A global analysis. Hydrology \& Earth System Sciences, 18(2).

Kyessi, A. G. (2005). Community-based urban water management in fringe neighbourhoods: The case of Dar es Salaam Tanzania. Habitat International, 29(1), 1-25.

Leonard, S., Parsons, M., Olawsky, K., \& Kofod, F. (2013). The role of culture and traditional knowledge in climate change adaptation: Insights from East Kimberley, Australia. Global Environmental Change, 23(3), 623-632. 
Lopes, V. A., Marques, G. F., Dornelles, F., \& MedellinAzuara, J. (2017). Performance of rainwater harvesting systems under scenarios of non-potable water demand and roof area typologies using a stochastic approach. Journal of Cleaner Production, 148, 304-313.

Mbilinyi, B. P., Tumbo, S. D., Mahoo, H. F., Senkondo, E. M., \& Hatibu, N. (2005). Indigenous knowledge as decision support tool in rainwater harvesting. Physics and Chemistry of the Earth, Parts a/b/c, 30(11-16), 792-798.

MacDonald, A. M., \& Calow, R. C. (2009). Developing groundwater for secure rural water supplies in Africa. Desalination, 248(1-3), 546-556.

Malesu, M. M. (2006). Rainwater harvesting innovations in response to water scarcity: The Lare experience (No. 5). World Agroforestry Centre.

Mancosu, N., Snyder, R., Kyriakakis, G., \& Spano, D. (2015). Water scarcity and future challenges for food production. Water, 7(3), 975-992.

Mekonnen, M. M., \& Hoekstra, A. Y. (2016). Four billion people facing severe water scarcity. Science Advances, 2(2).

Mekonnen, Z., Kidemu, M., Abebe, H., Semere, M., Gebreyesus, M., Worku, A., Tesfaye, M., \& Chernet, A. (2021). Traditional knowledge and institutions for sustainable climate change adaptation in Ethiopia. Current Research in Environmental Sustainability, 3, p.100080.

Mepaiyeda, S., Madi, K., Gwavava, O., \& Baiyegunhi, C. (2020). Geological and geophysical assessment of groundwater contamination at the Roundhill landfill site, Berlin, Eastern Cape. South Africa. Heliyon, 6(7), 04249.

Merétika, A. H. C., Peroni, N., \& Hanazaki, N. (2010). Local knowledge of medicinal plants in three artisanal fishing communities (Itapoá, Southern Brazil), according to gender, age, and urbanization. Acta Botanica Brasilica, 24(2), 386-394.

Mdoda, L. (2015). Farmers' awareness of climate change and variability and it's effects on agricultural productivity:(the case of King Sabata Dalindyebo Municipality in Eastern Cape. Unpublished Dissertation for Doctor of Philosophy. Alice: University of Fort Hare.

Mohammed, I., Alshuwaikhat, H. M., \& Adenle, Y. A. (2016). An approach to assess the effectiveness of smart growth in achieving sustainable development. Sustainability, 8(4), 397.

Montanari, B., \& Bergh, S. I. (2019). Why women's traditional knowledge matters in the production processes of natural product development: The case of the Green Morocco Plan. Women's Studies International Forum, 77, 102275.

Mukheibir, P. (2007). Qualitative assessment of municipal water resource management strategies under climate impacts: The case of the Northern Cape. South Africa. Water Sa, 33(4), 575-581.

Olagunju, A., Thondhlana, G., Chilima, J. S., Sène-Harper, A., Compaoré, W. N., \& Ohiozebau, E. (2019). Water governance research in Africa: Progress, challenges and an agenda for research and action. Water International, 44(4), 382-407.

Oweis, T., Hachum, A., \& Bruggeman, A. (2004). Indigenous water-harvesting systems in West Asia and North Africa Aleppo, Syria: International Center for Agricultural Research in the Dry Areas.
Paniagua-Zambrana, N.Y ., Camara-Lerét, R., Bussmann, R. W., \& Macía, M. J. (2014). The influence of socioeconomic factors on traditional knowledge: A cross scale comparison of palm uses in northwestern South America. Ecology and Society, 19(4).

Petzold, J., Andrews, N., Ford, J. D., Hedemann, C. \& Postigo, J. C. (2020). Indigenous knowledge on climate change adaptation: A global evidence map of academic literature. Environmental Research Letters, 15(11), 113007.

Quinlan, M. B., \& Quinlan, R. J. (2007). Modernization and medicinal plant knowledge in a Caribbean horticultural village. Medical Anthropology Quarterly, 21(2), 169-192.

R Development Core Team. (2017). A language and environment for statistical computing. Retrieved from http:// www.r-project.org

Ray, I. (2007). Women, water, and development. Annual Review of Environment and Resources, 32, 421-449.

Revenga, C., \& Cassar, A. (2002). Freshwater trends and projections: Focus on Africa.

Reyes-García, V., Guèze, M., Luz, A. C., Paneque-Gálvez, J., Macía, M. J., Orta-Martínez, M., Pino, J., \& RubioCampillo, X. (2013). Evidence of traditional knowledge loss among a contemporary indigenous society. Evolution and Human Behavior, 34(4), 249-257.

Saxena, D. (2017). Water conservation: Traditional rainwater harvesting systems in Rajasthan. International Journal of Engineering Trends and Technology, 52(2), 91-98.

Schewe, J., Heinke, J., Gerten, D., Haddeland, I., Arnell, N. W., Clark, D. B., Dankers, R., Eisner, S., Fekete, B. M., ColónGonzález, F. J., \& Gosling, S. N. (2014). Multimodel assessment of water scarcity under climate change. Proceedings of the National Academy of Sciences, 111(9), 3245-3250.

Shen, Y., Oki, T., Kanae, S., Hanasaki, N., Utsumi, N., \& Kiguchi, M. (2014). Projection of future world water resources under SRES scenarios: An integrated assessment. Hydrological Sciences Journal, 59(10), 1775-1793.

Singh, C., Osbahr, H., \& Dorward, P. (2018). The implications of rural perceptions of water scarcity on differential adaptation behaviour in Rajasthan. India. Regional Environmental Change, 18(8), 2417-2432.

Tabane, L. I. (2017). The effects of water scarcity on rural livelihoods: A case study of Borakalalo village in Lehurutshe (North West Province). Unpublished Dissertation for Doctor of Philosophy. Johannesburg: University of Witwatersrand.

Telles, T. S., Lourenco, M. A., Oliveira, J. F., Costa, G. V., \& Barbosa, G. (2019). Soil conservation practices in a watershed in Southern Brazil. Anais da Academia Brasileira de Ciências, 91(3).

Tekken, V., \& Kropp, J. P. (2012). Climate-driven or humaninduced: Indicating severe water scarcity in the Moulouya River Basin (Morocco). Water, 4(4), 959-982.

UN. (2018). Sustainable Development Goal 6: Synthesis Report on Water and Sanitation. https://sustainabledevelopment. un.org/content/documents/19901SDG6SR2018web3.pdf. Accessed 09 June 2019.

UN. (2019). World Water Development Report 2019: Leaving no one behind. https://www.unwater.org/worldwater-development-report-2019-leaving-no-one-behind/. Accessed 9 June 2019. 
UNESCO. (2012). http://www.unesco.org/new/en/venice/aboutthis-office/single-view/news/educating_school_kids_to_ watch_for_every_drop_of_water/. Accessed 13 August 2019.

Van Roon, M. (2007). Water localisation and reclamation: Steps towards low impact urban design and development. Journal of Environmental Management, 83(4), 437-447.

Van Mechelen, C., Dutoit, T., \& Hermy, M. (2015). Adapting green roof irrigation practices for a sustainable future: A review. Sustainable Cities and Society, 19, 74-90.

Veldkamp, T. I. E., Lasage, R., Ward, P., \& Gevaert, A. I. (2017). Water scarcity at the global and regional scales: unravelling its dominant drivers in historical and future time periods.

Villarreal, E. L., \& Dixon, A. (2005). Analysis of a rainwater collection system for domestic water supply in Ringdansen, Norrköping, Sweden. Building and Environment, 40(9), 1174-1184.

Voeks, R. A., \& Leony, A. (2004). Forgetting the forest: Assessing medicinal plant erosion in eastern Brazil. Economic Botany, 58(1), S294-S306.

Wada, Y., Van Beek, L. P. H., Viviroli, D., Dürr, H. H., Weingartner, R., \& Bierkens, M. F. (2011). Global monthly water stress: 2.
Water demand and severity of water stress. Water Resources Research, 47(7).

Weckmüller, H., Barriocanal, C., Maneja, R., \& Boada, M. (2019). Factors affecting traditional medicinal plant knowledge of the Waorani Ecuador. Sustainability, 11(16), 4460.

Yazdanpanah, M., Thompson, M., Hayati, D., \& Zamani, G. H. (2013). A new enemy at the gate: Tackling Iran's water super-crisis by way of a transition from government to governance. Progress in Development Studies, 13(3), 177-194.

Yineger, H., Yewhalaw, D., \& Teketay, D. (2008). Ethnomedicinal plant knowledge and practice of the Oromo ethnic group in southwestern Ethiopia. Journal of Ethnobiology and Ethnomedicine, 4(1), 1-10.

Zambrana, N. Y. P., Byg, A., Svenning, J. C., Moraes, M., Grandez, C., \& Balslev, H. (2007). Diversity of palm uses in the western Amazon. Biodiversity and Conservation, 16(10), 2771-2787.

Publisher's Note Springer Nature remains neutral with regard to jurisdictional claims in published maps and institutional affiliations. 